\title{
Breve homenagem a Marcelo Pimenta Marques
}

Foi a partir de um fato aparentemente trivial - esta é a última vez em que seu nome estará aparecendo no Comitê Editorial da Nuntius Antiquus - que pensei ser esta a ocasião, neste número da revista (ainda que não tenha sido organizado para este fim), para uma breve homenagem ao nosso colega Marcelo Pimenta Marques, que, para nossa grande tristeza e pesar, faleceu em 04 de agosto de 2016.

Obviamente, como boa parte dos classicistas brasileiros (e, especialmente, dos estudiosos de filosofia grega antiga) já sabe, Marcelo Marques deixou uma obra escrita significativa e filosófica no pleno sentido do termo, onde, além dos inúmeros artigos e capítulos de livro publicados (ou da organização de números temáticos da revista Kriterion), se destacam os livros $O$ caminho poético de Parmênides (São Paulo: Loyola, 1990), Platão, pensador da diferença (Belo Horizonte: Editora da UFMG, 2006), e - como organizador - Escritos. Filosofia viva de Sônia Viegas (Belo Horizonte: Tessitura, 2009), e ainda Teorias da imagem na Antiguidade (São Paulo: Paulus, 2012). Ele também esteve à frente da organização da instigante coleção "Contraposições", da Editora Paulus, a partir de 2012. Para informações mais detalhadas sobre sua obra escrita (e suas outras atividades) ainda é possível consultar hoje o seu bem organizado blog: http://marquess56.blogspot.com.br.

Como também seus colegas do Departamento de Filosofia da FAFICH-UFMG bem o sabem, inclusive melhor do que eu, Marcelo Marques foi alguém diretamente envolvido com questões institucionais tocando diretamente a transmissão do saber, como a organização e coordenação do curso de graduação de Filosofia, a reiterada preparação de material didático e a divulgação do conhecimento acadêmico fora da esfera universitária estrita (com o projeto "Filosofia na Praça"), além da dedicação habitual aos seus próprios cursos e de sua afetuosa disponibilidade no acolhimento de alunos interessados em filosofia grega antiga, especialmente os seus inúmeros orientandos, a quem ele foi sempre muito dedicado.

Mas o foco desta breve homenagem, uma vez que Nuntius Antiquus é a revista do Núcleo de Estudos Antigos e Medievais (NEAM) da UFMG (um núcleo interdisciplinar abrigando professores e 
pesquisadores da Grécia e Roma antigas e da Idade Média), é (ou, agora, foi) a participação aberta e atenta de Marcelo Marques nas atividades do NEAM, desde a sua fundação e mesmo antes dela, tornando possível um contato necessário e frutífero (regido pelo desejo de saber e a amizade) entre os que estudavam Grécia Antiga na Faculdade de Letras e no Departamento de Filosofia da FAFICH da UFMG, algo que se abriu para intercâmbios e trocas em inúmeras bancas de defesa de dissertações e teses, além da organização de (ou participação em) eventos cujo interesse era comum para os dois grupos.

Ora, antes mesmo da fundação do NEAM, iniciativa pioneira de Jacyntho Lins Brandão no começo dos anos 2000, e depois dela ainda durante algum tempo, alguns professores e alunos da Filosofia e da Letras se reuniam semanal ou quinzenalmente para lerem e comentarem os originais de textos gregos antigos de poetas, filósofos e historiadores (como Homero, Platão, Aristóteles, Tucídides e Xenofonte), em um grupo que - em homenagem ao termo grego para leitura (que literalmente quer dizer "reconhecimento") - foi chamado de Anágnosis. Neste grupo, que contou com a participação de Antonio Orlando de Oliveira Dourado Lopes e a minha, e, um pouco depois, a de Matheus Trevizam (FALE-UFMG), assim como a de Fernando Rey Puente e a de Cláudio Veloso (Departamento de Filosofia da FAFICH-UFMG), Marcelo Marques foi sempre generoso em sua curiosidade e empenho, além de contribuir decisivamente, com seu bom humor e afabilidade, para um raro e delicado prazer da convivência entre seres humanos que se dedicam seriamente a uma mesma ou análoga atividade. Ainda ressoa viva em minha memória a sua deliciosa e sábia gargalhada. Minha saudade é imensa.

Teodoro Rennó Assunção (em nome dos editores da revista) 